Article

\title{
Exploring Adsorption Process of Lead (II) and Chromium (VI) Ions from Aqueous Solutions on Acid Activated Carbon Prepared from Juniperus procera Leaves
}

\author{
Ismat H. Ali ${ }^{1, *(1)}$, Mohammed K. Al Mesfer ${ }^{2}$, Mohammad I. Khan ${ }^{2}$, Mohd Danish ${ }^{2}$ and \\ Majed M. Alghamdi ${ }^{1}$ \\ 1 Department of Chemistry, College of Science, King Khalid University, Abha 61413, Saudi Arabia; \\ mmalghamdi@kku.edu.sa \\ 2 Chemical Engineering Department, College of Engineering, King Khalid University, Abha 61321, \\ Saudi Arabia; almesfer@kku.edu.sa (M.K.A.M.); mkaan@kku.edu.sa (M.I.K.); mdansh@kku.edu.sa (M.D.) \\ * Correspondence: ismathassanali@gmail.com
}

Received: 1 March 2019; Accepted: 10 April 2019; Published: 16 April 2019

check for updates

\begin{abstract}
The adsorption potential of acid activated carbon prepared from leaves of Juniperus procera to remove $\mathrm{Pb}(\mathrm{II})$ and $\mathrm{Cr}(\mathrm{VI})$ toxic ions from aqueous solutions was investigated. The effects of solution $\mathrm{pH}$, adsorbent mass, contact time, initial ion concentration and temperature on the biosorption process were studied, and the optimum conditions were determined. Moreover, Langmuir, Freundlich, Temkin and Dubinin-Radushkevich adsorption isotherm models were applied to analyze adsorption data. Thermodynamic parameters for the adsorption processes were calculated. Adsorption was found to be a spontaneous and endothermic process. In addition, kinetic studies revealed a pseudo-first order kinetics biosorption process. The obtained results suggest that acid activated Juniperus procera leaves powder can be used as a cheap, efficient and environmentally friendly adsorbent material with high removal efficiency up to $98 \%$ for $\mathrm{Pb}$ (II) and $96 \%$ for $\mathrm{Cr}(\mathrm{VI})$ at 0.80 and $1.00 \mathrm{~g} / 100 \mathrm{~mL}$, respectively. The duration of the process was $100 \mathrm{~min}$ and $120 \mathrm{~min}$ for $\mathrm{Pb}(\mathrm{II})$ and $\mathrm{Cr}(\mathrm{VI})$ ions, respectively. The morphology of the of prepared activated carbon was investigated by scanning electron microscope (SEM).
\end{abstract}

Keywords: Juniperus procera leaves; acid activation; adsorption; isotherm models

\section{Introduction}

Recent trends in human growth and their subsequent needs of everyday life have prompted a boom in the development of all industrial sectors from basic food and water processing to luxurious cars and other expensive gadgets production. However, one of the drawbacks of all this is that it puts a huge burden on the available natural resources and increases pollution levels that in turn lead to catastrophic effects on the environment and human health. Chromium and lead are common pollutants in wastewater resulting from numerous industrial activities including electroplating, paint manufacturing plants, textile manufacturing, steel, leather tanning, ceramic and glass industries, petroleum refining, battery manufacture, mining operations and other metal finishing industries. As they are toxic and non-degradable, they have a significant effect on the whole ecosystem with direct effects on human health. $\mathrm{Pb}$ (II) can cause damage to the central nervous system, kidneys, liver and reproductive systems. Symptoms related to the presence of $\mathrm{Pb}(\mathrm{II})$ include headache, dizziness, irritability, weakness of muscles, etc. [1]. As for the chromium, $\mathrm{Cr}(\mathrm{VI})$ is reported to be more toxic than $\mathrm{Cr}(\mathrm{III})$ and severely affects human physiology [2]. 
To overcome these concerns, various strategies have been used to remove heavy metals such as the use of simple desalination, evaporation, reverse osmosis, and ion exchange. However, the recent biosorption technique is environmentally friendly and affordable. Biosorption is a natural biological method and is considered as a good alternative to conventional wastewater treatment methods.

Removal of $\mathrm{Pb}(\mathrm{II})$ and $\mathrm{Cr}(\mathrm{VI})$ from wastewater has been widely explored. For example, in the case of $\mathrm{Cr}(\mathrm{VI})$, the use of materials such as rice straw activated carbon [3], apple pulp [4], activated carbon developed from Terminalia arjuna nuts [5], activated carbon from hazelnut [6], sawdust [7], sugarcane baggas [8], activated carbon from mango kernel [9], egg shell and powdered marble [10], rice husk activated carbon [11] and apple peel powder [4] have been explored and reported in the literature. Moreover, numerous studies are available for $\mathrm{Pb}(\mathrm{II})$ removal from wastewater. Some recent studies include the use of cocoa shells [12], maize tassel based activated carbon [13], coconut shell [14], activated periwinkle shells [15], bamboo activated carbon [16], caltropis plants roots [17], cashew nut shells [18], activated carbons derived from oil palm and coconut shells [19], mixture of charcoal and peanut shells [20], Moringa oleifera bark [21], pumpkin seeds [22], rice husk-based activated carbon $[23,24]$ and untreated orange barks [25].

However, most of the reported adsorbents can only remove a single metal ion. This paper highlights that the adsorbent used in the current investigation could efficiently remove two metal ions from aqueous solutions. Furthermore, the method of generation of the adsorbent is robust and cost effective, as it does not require any high temperature treatment. In addition, to the removal of two metal ions and simple regeneration, the adsorbent can be effectively used at least three times before being discarded. To our knowledge, few biosorbents are capable of removing both $\mathrm{Pb}$ (II) and $\mathrm{Cr}(\mathrm{VI})$ from aqueous solutions while being efficiently reusable at least three times. Juniperus procera is the most abundant plant in Aseer region, Saudi Arabia. The use of leaves of this plant as a low-cost biosorbent material for $\mathrm{Pb}(\mathrm{II})$ and $\mathrm{Cr}(\mathrm{VI})$ ions is not yet been reported in the literature. Hence, this study focused on the exploitation of this new and environmentally friendly material for $\mathrm{Pb}$ (II) and $\mathrm{Cr}(\mathrm{VI}))$ ion removal from artificial wastewater.

\section{Materials and Methods}

\subsection{Chemicals and Instruments}

All chemicals used in this work were purchased from Merck, Germany and BDH, England and used without further purifications. Aqueous stock solutions of $\mathrm{Pb}(\mathrm{II})$ and $\mathrm{Cr}(\mathrm{VI})$ ions were prepared from lead acetate and potassium dichromate in deionized water. Various concentrations, ranging $50-300 \mathrm{mg} / \mathrm{L}$, were obtained by diluting the stock solutions.

Hydrochloric acid and sodium hydroxide solutions were used for $\mathrm{pH}$ adjustment. The $\mathrm{pH}$ measurements were carried out by a pH meter (Hanna 211 model). Metal ions concentrations in the treated solutions were determined using an atomic absorption spectrometer (Spectra AA 20).

\subsection{Leaves Collection, Preparation and Carbonization}

To carry out the experimental work, Juniperus procera leaves were collected from Abha City in Saudi Arabia. Theses leaves were thoroughly washed with deionized water to remove any fines, dirt and dust. The leaves were dried at $40^{\circ} \mathrm{C}$ for $3 \mathrm{~h}$, crushed and sieved to a particle size with $100 \mu \mathrm{m}$. The obtained leaves powder was then immersed in diethyl ether and left overnight to allow solvent and volatile oil removal by simple evaporation. This step was followed by acid activation in which sulfuric acid was added to the sample in a 1:1.8 ratio, as reported by Singanan [26]. The mixture was continuously stirred for $30 \mathrm{~min}$ followed by filtration and rinsing thoroughly with deionized water to remove any residual acid. The activated leaves were then sieved again with $100 \mu \mathrm{m}$ mesh and stored in desiccators [27]. 


\subsection{Reliability of Results}

Sensitivity of the measurements was estimated by determination of limit of detection (LOD) and limit of quantitation (LOQ). LOD and LOQ, were determined by measuring 10 blank samples and then applying the relationships $3.3 \mathrm{SD} / \mathrm{b}$ and $10 \mathrm{SD} / \mathrm{b}$, respectively. The precision of measurements is usually expressed as relative standard deviation (RSD). Precision was determined by assessing the reproducibility of the results. The same conditions were used to measure 10 blank samples. Typically, recovery studies are performed to determine the accuracy of the measurements. Recovery studies were accomplished by spiking technique.

\subsection{Batch Adsorption Studies}

Batch experiments for biosorption of $\mathrm{Pb}(\mathrm{II})$ and $\mathrm{Cr}(\mathrm{VI})$ ions on acid activated Juniperus procera leaves (AAJPL) were carried out. The desired amounts of the AAJPL were added to glass flasks containing different concentrations of $\mathrm{Pb}(\mathrm{II})$ and $\mathrm{Cr}(\mathrm{VI})$ solutions with concentrations ranging from 50 to $300 \mathrm{mg} / \mathrm{L}$. Throughout the experiments, the flask was put on a temperature controlled magnetic stirrer with a stirring speed of $150 \mathrm{rpm}$ for the required period of time. Biosorption quantity was calculated using Equation (1):

$$
\mathrm{q}_{\mathrm{e}}=\frac{\mathrm{C}_{\mathrm{o}}-\mathrm{C}_{\mathrm{e}}}{\mathrm{M}} \times \mathrm{V}
$$

where $\mathrm{V}$ is the volume of the metal solution in the flask, $\mathrm{q}_{\mathrm{e}}$ is the metal uptake capacity $(\mathrm{mg} / \mathrm{g}), \mathrm{M}$ is the dry mass of biosorbent $(\mathrm{g}), \mathrm{C}_{\mathrm{o}}$ is the initial metal ions concentration, and $\mathrm{C}_{\mathrm{e}}$ is the metal ions concentration at the equilibrium. The overall removal efficiency $(\mathrm{R} \%)$ of metal ions was determined using Equation (2). All experiments were carried out in duplicate and the average value was used for further calculation.

$$
\mathrm{R} \%=\frac{\mathrm{C}_{\mathrm{o}}-\mathrm{C}_{\mathrm{e}}}{\mathrm{C}_{\mathrm{o}}} \times 100
$$

\subsection{Control Experiments}

Control experiments were carried out using the ground Juniperus procera leaves without activation. Other experiments were carried out using $\mathrm{Pb}(\mathrm{II})$ and $\mathrm{Cr}(\mathrm{VI})$ solutions without biosorbent to measure the quantity of ions that may be adsorbed by walls of the glass bottle and magnetic stirrer.

\subsection{Reactivation of $A A J P L$}

AAJPL was reactivated by shaking with bi-distilled water for $24 \mathrm{~h}$, and then it was filtered and heated overnight at $105^{\circ} \mathrm{C}$ The conditions of these experiments were kept identical to the optimal conditions of the adsorption process.

\section{Results and Discussion}

\subsection{Reliability of the Measurements}

Precision of the measurements was found to be $5.6 \%$, whereas the accuracy was determined as $95.3 \%$, which are in the acceptable range.

\subsection{Effect of $p H$}

Biosorption efficiency of the system strongly depends on the $\mathrm{pH}$ of the solutions. The data presented in Figure 1 highlight the effect of the $\mathrm{pH}$ on biosorption of $\mathrm{Pb}(\mathrm{II})$ and $\mathrm{Cr}(\mathrm{VI})$ ions onto AAJPL. The biosorption increased and attained the maximum values for $\mathrm{Pb}(\mathrm{II})$ and $\mathrm{Cr}(\mathrm{VI})$ at $\mathrm{pH} 4.6$ and 4, respectively. At $\mathrm{pH}$ higher than 6, biosorption activity decreased. This may be attributed to the diminution of free ions due to the formation of hydroxyl complexes at the higher $\mathrm{pH}$ range, as reported in [28-30], and the subsequent precipitation of metal ions; thus, removal efficiency dropped sharply. 


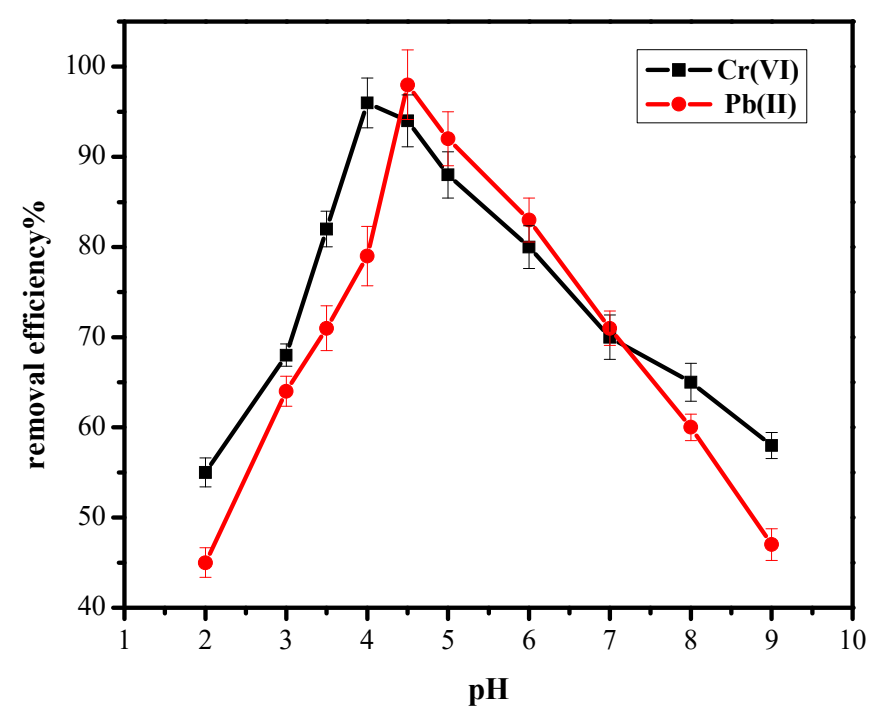

Figure 1. Effect of $\mathrm{pH}$ on biosorption of $\mathrm{Pb}(\mathrm{II})$ and $\mathrm{Cr}(\mathrm{VI})$ ions on AAJPL (adsorbent mass: $0.80 \mathrm{~g} / 100 \mathrm{~mL}$ for $\mathrm{Pb}$ (II) and $1.00 \mathrm{~g} / 100 \mathrm{~mL}$ for $\mathrm{Cr}(\mathrm{VI})$; metal ion concentrations: $50 \mathrm{mg} / \mathrm{L}$ for $\mathrm{Pb}(\mathrm{II})$ and $70 \mathrm{mg} / \mathrm{L}$ for $\mathrm{Cr}(\mathrm{VI})$; temperature: $\left.25^{\circ} \mathrm{C}\right)$.

On the other hand, at $\mathrm{pH}$ values lower than the optimum, biosorption activity may have been hindered by the $\mathrm{H}^{+}$and metal ions competing for the same active sites on the same active sites on the adsorbent surface [26].

\subsection{Effect of Biosorbent Mass}

To accomplish this task, series of batch experiments were performed with the adsorbent mass of $0.10,0.20,0.40,0.60,0.80,1.00,1.25,1.5$ and 2.0 g per $100 \mathrm{~mL}$ of aqueous solutions of $\mathrm{Pb}$ (II) and $\mathrm{Cr}(\mathrm{VI})$ ions. Figure 2 clearly shows that, as the mass of biosorbent increased, the removal efficiency of metal ions also increased. A maximum removal efficiency of $98 \%$ for $\mathrm{Pb}(\mathrm{II})$ and $96 \%$ for $\mathrm{Cr}(\mathrm{VI})$ was obtained at 0.80 and $1.00 \mathrm{~g} / 100 \mathrm{~mL}$ of the AAJPL, respectively. In addition, a further increase of biosorbent mass was found to have no significant effect on the removal of both ions from their aqueous solutions.

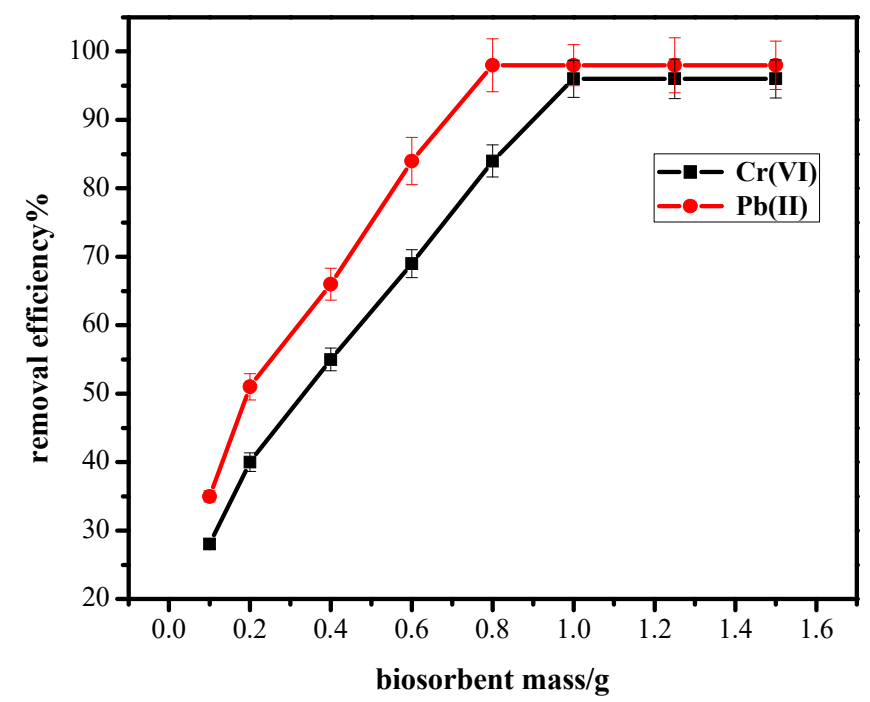

Figure 2. Effect of biosorbent mass on the removal efficiency of $\mathrm{Pb}(\mathrm{II})$ and $\mathrm{Cr}(\mathrm{VI})$ from aqueous solutions (metal ion concentrations: $50 \mathrm{mg} / \mathrm{L}$ for $\mathrm{Pb}(\mathrm{II})$ at $\mathrm{pH} 4.6$ and $70 \mathrm{mg} / \mathrm{L} \mathrm{pH} 4$ for and $\mathrm{Cr}(\mathrm{VI})$; temperature: $\left.25^{\circ} \mathrm{C}\right)$. 


\subsection{Effect of Metal Ion Concentration}

The biosorption of $\mathrm{Pb}(\mathrm{II})$ and $\mathrm{Cr}(\mathrm{VI})$ ions was carried out at various concentrations of $\mathrm{Pb}(\mathrm{II})$ and $\mathrm{Cr}(\mathrm{VI})$ ranging from 50 to $300 \mathrm{mg} / \mathrm{L}$ using $0.80 \mathrm{~g}$ and $1.00 \mathrm{~g}$ of AAJPL. Results shown in Figure 3 reveal that the maximum achieved adsorption was 50 and $70 \mathrm{mg} / \mathrm{L}$ for $\mathrm{Pb}(\mathrm{II})$ and $\mathrm{Cr}(\mathrm{VI})$ ions, respectively. This could be attributed to the fact that the active sites are covered and saturated as the concentrations increase.

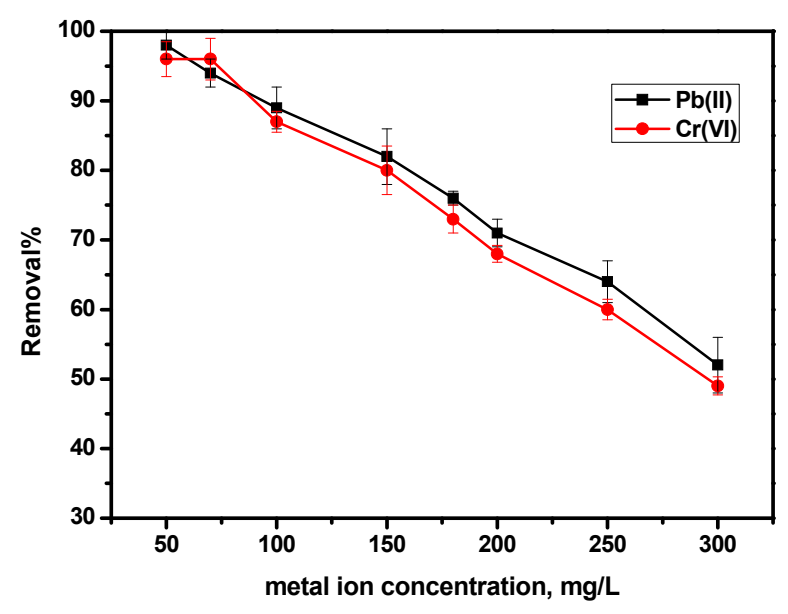

Figure 3. Effect of metal ion concentrations on the adsorption efficiency.

It is well established that the addition of salts to a tested solution may lead to decrease of the maximum adsorption capacity $\mathrm{q}_{\max }$. This can be ascribed to the presence of more ions that compete for limited adsorption sites [31].

\subsection{Effect of Contact Time}

The effect of contact time on biosorption of $\mathrm{Pb}(\mathrm{II})$ and $\mathrm{Cr}(\mathrm{VI})$ ions onto AAJPL was studied using the optimum biosorbent dosage values of 0.80 and $1.0 \mathrm{~g} / 100 \mathrm{~mL}$ obtained earlier. The experiments were carried out at $25{ }^{\circ} \mathrm{C}$ with optimum concentration values of metal ions, viz. 50.0 and $70.0 \mathrm{mg} / \mathrm{L}$ for $\mathrm{Pb}$ (II) and $\mathrm{Cr}(\mathrm{VI})$ ions, respectively. As shown in Figure 4, maximum removal efficiencies of $98 \%$ and $96 \%$ were achieved after 100 and $120 \mathrm{~min}$ for the metals under investigation. Moreover, a further increase in contact time had no significant influence on the removal of both metal ions.

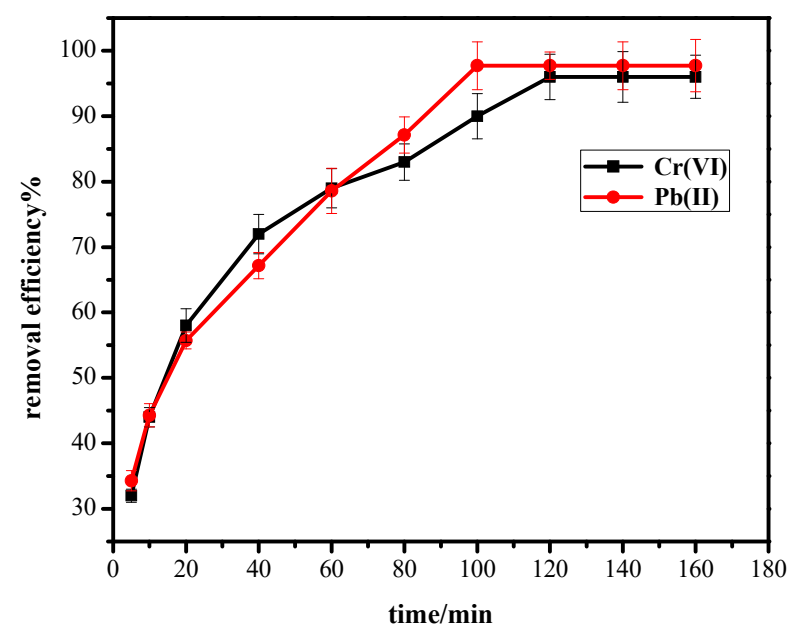

Figure 4. Effect of time on removal efficiency of $\mathrm{Pb}(\mathrm{II})$ and $\mathrm{Cr}(\mathrm{VI})$ ions on AAJPL (adsorbent mass: $0.80 \mathrm{~g} / 100 \mathrm{~mL}$ for $\mathrm{Pb}(\mathrm{II})$ at $\mathrm{pH} 4.6$ and $1.00 \mathrm{~g} / 100 \mathrm{~mL}$ for $\mathrm{Cr}(\mathrm{VI})$ at $\mathrm{pH} 4$; metal ion concentrations: $50 \mathrm{mg} / \mathrm{L}$ for $\mathrm{Pb}(\mathrm{II})$ and $70 \mathrm{mg} / \mathrm{L}$ for $\mathrm{Cr}(\mathrm{VI})$; temperature: $\left.25^{\circ} \mathrm{C}\right)$. 


\subsection{Biosorption Isotherms}

Adsorption isotherms describe the interaction between adsorbate and adsorbents and express the relationship between the sorption capacity and equilibrium concentration. Biosorption of $\mathrm{Pb}$ (II) and $\mathrm{Cr}(\mathrm{VI})$ ions onto AAJPL was analyzed by means of four adsorption isotherms: Langmuir, Freundlich, Temkin and D-R isotherms.

\subsubsection{Langmuir Isotherm}

Adsorption in the Langmuir isotherm model is assumed to occur as a monolayer on a uniform surface with a fixed number of adsorption sites [18]. When a site is filled, no further adsorption can occur at that site. Thus, the adsorbent surface will reach its saturation point where the maximum adsorption is attained. When applying the linear equation of Langmuir isotherm model given by Equation (3), a linear plot was obtained, as shown in Figure 5.

$$
\frac{\mathrm{C}_{\mathrm{e}}}{\mathrm{q}_{\mathrm{e}}}=\frac{1}{\mathrm{~K}_{\mathrm{L}} \mathrm{q}_{\max }}+\frac{\mathrm{C}_{\mathrm{e}}}{\mathrm{q}_{\max }}
$$

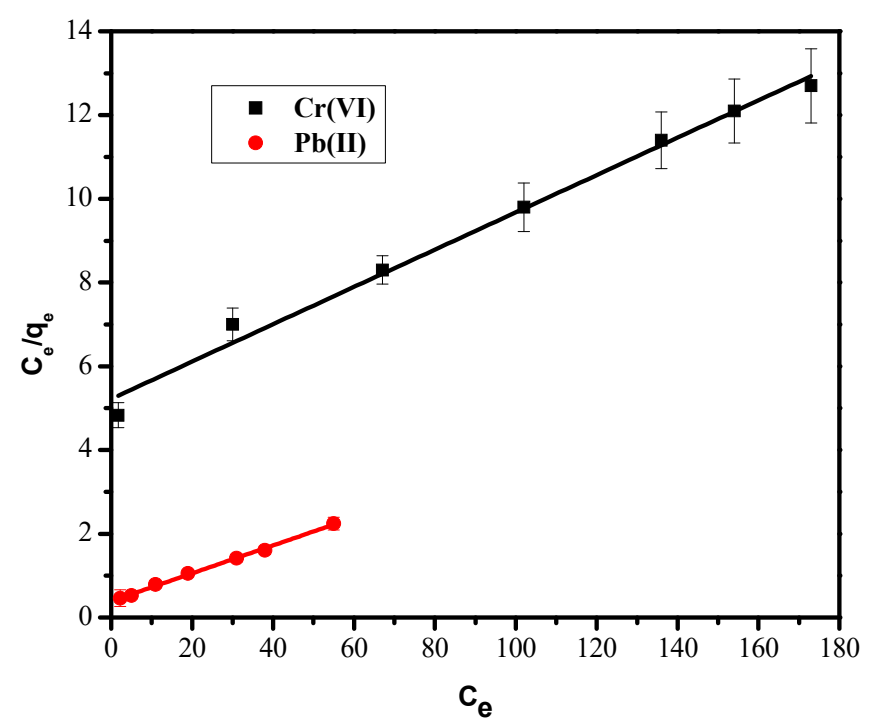

Figure 5. Linear fit of experimental data obtained using Langmuir isotherm model (adsorbent mass: $0.80 \mathrm{~g} / 100 \mathrm{~mL}$ for $\mathrm{Pb}(\mathrm{II})$ at $\mathrm{pH} 4.6$ and $1.00 \mathrm{~g} / 100 \mathrm{~mL}$ for $\mathrm{Cr}(\mathrm{VI})$ at $\mathrm{pH} 4.0$; temperature: $25^{\circ} \mathrm{C}$ ).

Here, $\mathrm{K}_{\mathrm{L}}$ is the Langmuir constant related to the adsorption energy and $\mathrm{q}_{\max }$ is the maximum uptake capacity $(\mathrm{mg} / \mathrm{g})$. Values of $\mathrm{q}_{\max }$ and $\mathrm{K}_{\mathrm{L}}$ were determined from the slope and intercept of the graph presented in Figure 5.

In addition, values of the parameters derived from Langmuir isotherm model are tabulated in Table 1. Furthermore, significant evidence related to sorption nature can be deduced from the separation factor $\left(R_{L}\right)$ values, which is an important characteristic of Langmuir isotherm. It can be used to understand the attraction/interactions between the sorbent and sorbate. Values of $R_{L}$ were calculated from Equation (4):

$$
R_{L}=\frac{1}{1+K_{L} C_{o}}
$$

where $C_{o}$ is the maximum preliminary concentration of the metal ions. The $R_{L}$ values indicate the type of adsorption as unfavorable $\left(R_{L}>1\right)$, linear $\left(R_{L}=1\right)$, favorable $\left(0<R_{L}>1\right)$ or irreversible $\left(R_{L}=0\right)$. In this study, the $\mathrm{R}_{\mathrm{L}}$ values indicated that the biosorption of $\mathrm{Pb}$ (II) and $\mathrm{Cr}(\mathrm{VI})$ ions onto AAJPL was a favorable process with values of 0.05 and 0.25 , respectively. 
Table 1. Adsorption isotherm constants obtained from the four adsorption models.

\begin{tabular}{|c|c|c|c|}
\hline \multicolumn{4}{|c|}{ Langmuir Isotherm } \\
\hline & $\mathrm{q}_{\max }, \mathrm{mg} / \mathrm{g}$ & $\mathrm{K}_{\mathrm{L}}, \mathrm{L} / \mathrm{g}$ & $\mathrm{R}^{2}$ \\
\hline $\mathrm{Pb}(\mathrm{II})$ & 30.3 & 0.08 & 0.997 \\
\hline $\mathrm{Cr}(\mathrm{VI})$ & 23.0 & 0.01 & 0.991 \\
\hline \multicolumn{4}{|c|}{ Freundlich Isotherm } \\
\hline & $\mathrm{n}$ & $\begin{array}{c}\mathrm{K}_{\mathrm{f}}, \\
(\mathrm{mg} / \mathrm{g}) /(\mathrm{mg} / \mathrm{L})^{\mathrm{n}}\end{array}$ & $\mathrm{R}^{2}$ \\
\hline $\mathrm{Pb}(\mathrm{II})$ & 0.50 & 21.23 & 0.965 \\
\hline $\mathrm{Cr}(\mathrm{VI})$ & 0.20 & 24.45 & 0.920 \\
\hline \multicolumn{4}{|c|}{ Temkin isotherm } \\
\hline & A, L/g & B & $\mathrm{R}^{2}$ \\
\hline $\mathrm{Pb}(\mathrm{II})$ & 0.89 & 6.45 & 0.992 \\
\hline $\mathrm{Cr}(\mathrm{VI})$ & 0.23 & 3.29 & 0.935 \\
\hline \multicolumn{4}{|c|}{ D-R isotherm } \\
\hline & $\beta$ & $\mathrm{q}_{\max }, \mathrm{mg} / \mathrm{g}$ & $\mathrm{R}^{2}$ \\
\hline $\mathrm{Pb}(\mathrm{II})$ & $2.0 \times 10^{-6}$ & 20.1 & 0.851 \\
\hline $\mathrm{Cr}(\mathrm{VI})$ & $8.0 \times 10^{-5}$ & 13.5 & 0.712 \\
\hline
\end{tabular}

\subsubsection{Freundlich Isotherm}

The Freundlich isotherm was also applied to the biosorption data. This model is an empirical expression and applies to adsorption on heterogeneous surfaces with the interaction between adsorbed molecules. Application of Freundlich isotherm model proposes an exponential decrease in adsorption energy upon completion of the sorption centers of sorbent. The linear form of Freundlich isotherm model can be described by Equation (5):

$$
\ln q_{e}=\ln K_{f}+\frac{1}{n} \ln C_{e}
$$

where $\mathrm{K}_{\mathrm{f}}$ is the relative adsorption capacity of the sorbent that is associated with the bonding energy and $\mathrm{n}$ is the heterogeneity factor expressing the deviation from linearity of biosorption. A plot of $\ln \mathrm{q}_{\mathrm{e}}$ against $\ln C_{e}$ was used to validate Freundlich adsorption isotherm. Values of $K_{f}$ and $n$ were determined from the intercept and slope of Figure 6 and the values obtained are listed in Table 1. In this model, the $\mathrm{n}$ values determine the degree of nonlinearity between solution concentration and adsorption in the following manner: if $n=1$, then adsorption is linear; if $n>1$, then adsorption is a chemical process; and if $\mathrm{n}<1$, adsorption is considered as a physical process. The obtained numerical values of $\mathrm{n}$ for $\mathrm{Pb}$ (II) and $\mathrm{Cr}(\mathrm{VI})$ ions removal were found to be 0.50 and 0.20 , indicating physical adsorption processes. 


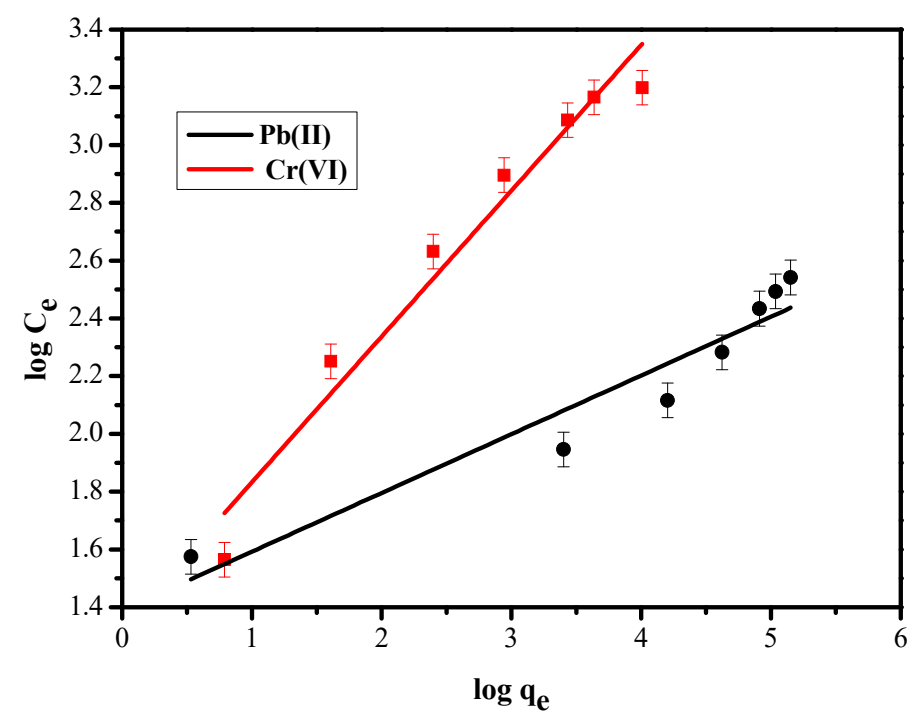

Figure 6. Linear fit of experimental data obtained using Freundlich isotherm model (adsorbent mass: $0.80 \mathrm{~g} / 100 \mathrm{~mL}$ for $\mathrm{Pb}(\mathrm{II})$ at $\mathrm{pH} 4.6$ and $1.00 \mathrm{~g} / 100 \mathrm{~mL}$ for $\mathrm{Cr}(\mathrm{VI})$ at $\mathrm{pH} 4.0$; temperature: $25^{\circ} \mathrm{C}$ ).

\subsubsection{Temkin Isotherm}

In Temkin isotherm model, the sorption heat of all molecules in the layer is assumed to decrease linearly with coverage of the sorbent surface because of a decrease in the adsorbent-adsorbate interactions. Temkin isotherm model can be described by Equation (6):

$$
q_{e}=B \ln A+B \ln C_{e}
$$

where $B=(R T) / b_{t}, T$ is the absolute temperature and $R$ is the universal gas constant. The constant $\mathrm{b}_{\mathrm{t}}$ is related to the heat of adsorption $(\mathrm{J} / \mathrm{mol})$. A is the equilibrium binding constant corresponding to the maximum binding energy. Values of $A$ and $B$ were calculated from slope and intercept of Equation (6), as displayed in Table 1. Values of $b_{t}$ for $\mathrm{Pb}(\mathrm{II})$ and $\mathrm{Cr}(\mathrm{VI})$ sorption were determined as 387 and $753 \mathrm{~J} / \mathrm{mol}$, respectively, indicating physical adsorption processes.

\subsubsection{Dubinin-Radushkevich (D-R) Isotherm}

Dubinin-Radushkevich (D-R) isotherm model was also used to describe the sorption data. It explains the adsorption nature and is usually used to determine the mean free energy of the sorption process [32]. The linear form of the D-R isotherm is given by Equation (7):

$$
\ln q_{e}=\ln q_{\max }-\beta \varepsilon^{2}
$$

where $\varepsilon$ is:

$$
\varepsilon=R T \ln \left(1+\frac{1}{C_{e}}\right)
$$

In Equations (7) and (8), $\mathrm{T}$ refers to the absolute temperature, $\mathrm{R}$ is the universal gas constant, and $\mathrm{q}_{\max }$ and $\beta$ are the $\mathrm{D}-\mathrm{R}$ isotherm constants. The $\mathrm{D}-\mathrm{R}$ isotherm constants $\mathrm{q}_{\max }$ and $\beta$ were calculated from the intercept and slope of Equation (7), as shown in Table 1. The mean free energy of adsorption process, $E_{f}$, is defined as the free energy change when one mole of ions is moved to the solid surface from infinity in solution and can be determined from Equation (9).

$$
E_{f}=\frac{1}{\sqrt{2 \beta}}
$$


It is known that the magnitude of $E_{\mathrm{f}}$ is useful for estimating the type of adsorption. For $8<\mathrm{E}_{\mathrm{f}}<$ $16 \mathrm{~kJ} / \mathrm{mol}$, the adsorption is classified as chemisorption process, and, when $\mathrm{E}_{\mathrm{f}}<8 \mathrm{~kJ} / \mathrm{mol}$, the adsorption is a physical process. In this study, lower values of $E_{\mathrm{f}}$ were found, viz. $2.42 \mathrm{~kJ} / \mathrm{mol}$ and $1.84 \mathrm{~kJ} / \mathrm{mol}$ for $\mathrm{Pb}$ (II) and $\mathrm{Cr}(\mathrm{IV})$, respectively, indicating that the adsorption processes were of physical type.

\subsection{Effect of Temperature}

To investigate the effect of temperature on the biosorption of $\mathrm{Pb}(\mathrm{II})$ and $\mathrm{Cr}(\mathrm{VI})$ ions onto AAJPL, experiments were conducted in temperatures ranging from 25.0 to $40.0^{\circ} \mathrm{C}$, under the optimal conditions determined previously. Results presented in Figure 7 reveal that the removal efficiency increased with increasing temperature. The maximum removal of metal ions from aqueous solutions was achieved at $40.0^{\circ} \mathrm{C}$ for both metal ions under investigation. This may be ascribed to: (i) activation of more sites on the sorbent surface as the temperature increased; and (ii) cations speed increased at elevated temperatures.

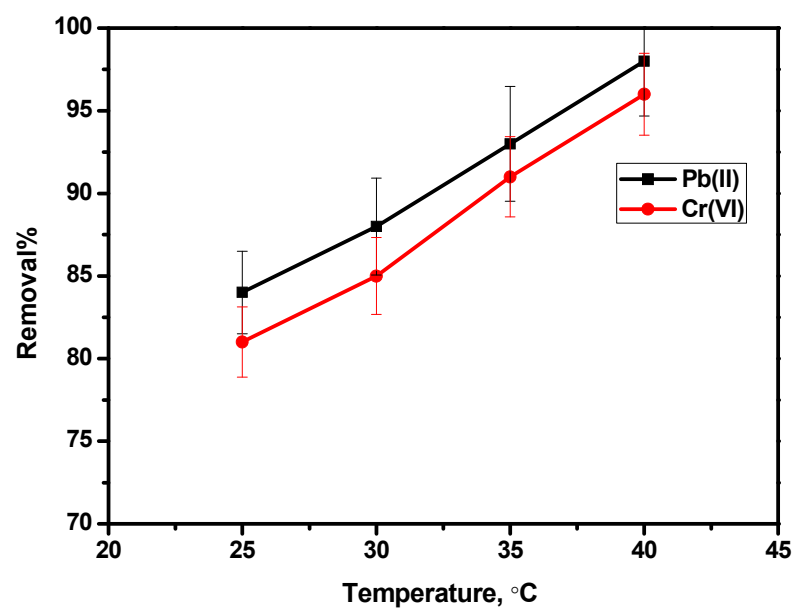

Figure 7. Effect of temperature on the adsorption efficiency of $\mathrm{Pb}(\mathrm{II})$ and $\mathrm{Cr}(\mathrm{VI})$ on AAJPL.

Thermodynamic Parameters

Some thermodynamic activation parameters, viz., entropy change of activation $\Delta \mathrm{S}^{\circ}$, enthalpy change of activation $\Delta \mathrm{H}^{\circ}$ and free energy change of activation $\Delta \mathrm{G}^{\circ}$, were calculated using Equations (10)-(12)

$$
\Delta G^{\circ}=R T \ln K_{D}
$$

In Equation (10), the parameter $K_{D}$ is the distribution coefficient and equal to the initial concentration $\left(C_{0}\right)$ divided by the final concentration $\left(C_{e}\right)$. The free energy change with respect to the entropy change of activation is given in Equation (11):

$$
\Delta G^{\circ}=\Delta H^{\circ}-T \Delta S^{\circ}
$$

Substituting Equation (10) into Equation (11) and rearranging leads to:

$$
\ln K_{D}=\frac{-\Delta H^{o}}{R T}+\frac{\Delta S^{o}}{R}
$$

Enthalpy and entropy change were calculated from the slope and intercept of Equation (12), respectively, while values of free energy change of activation $\Delta \mathrm{G}^{\circ}$ were determined from Equation (10).

Numerical values of the free energy change $\left(\Delta \mathrm{G}^{\circ}\right)$ are shown in Table 2 . The obtained negative values indicate that the biosorption process was spontaneous. In addition, it can be noticed that, as the temperature increased, the negative values of free energy change increased. This may be attributed to the fact that more sites on the surface of AAJPL were activated with the rise in temperature. Values of 
free energy change $\Delta \mathrm{G}^{\circ}$ for $\mathrm{Pb}(\mathrm{II})$ and $\mathrm{Cr}(\mathrm{VI})$ biosorption onto AAJPL were found in the ranges of -2.5 to $-11.7 \mathrm{~kJ} / \mathrm{mol}$ for $\mathrm{Pb}$ (II) ions and -4.2 to $-11.0 \mathrm{~kJ} / \mathrm{mol}$ for $\mathrm{Cr}(\mathrm{VI})$ ions. As it is known that physical adsorption free energy change $\left(\Delta \mathrm{G}^{\circ}\right)$ ranges between -20 and $0 \mathrm{~kJ} / \mathrm{mol}$ and chemical adsorption between -80 to $-400 \mathrm{~kJ} / \mathrm{mol}$, the adsorption process was predominantly a physical biosorption process. This is in good agreement with results derived from $n, E_{f}$ and $b_{t}$ values of Freundlich, (D-R) and Temkin isotherms.

Table 2. Thermodynamic parameters of the biosorption of $\mathrm{Pb}$ (II) and $\mathrm{Cr}$ (VI) ions onto AAJPL.

\begin{tabular}{|c|c|c|c|c|}
\hline $\mathrm{T}, \mathrm{K}$ & $\overline{K_{D}}$ & $\Delta G^{\circ}(\mathrm{kJ} / \mathrm{mol})$ & $\Delta \mathrm{H}^{\circ}(\mathrm{kJ} / \mathrm{mol})$ & $\Delta S^{\circ}(\mathrm{J} / \mathrm{mol} \mathrm{K})$ \\
\hline \multicolumn{5}{|l|}{$\mathrm{Pb}(\mathrm{II})$} \\
\hline 298 & 22.83 & -2.5 & 107.58 & 369.3 \\
\hline 303 & 5.36 & -4.3 & & \\
\hline 313 & 2.50 & -8.0 & & \\
\hline 323 & 1.41 & -11.7 & & \\
\hline \multicolumn{5}{|l|}{$\mathrm{Cr}(\mathrm{VI})$} \\
\hline 298 & 22.86 & -4.2 & 78.59 & 274.4 \\
\hline 303 & 9.78 & -5.5 & & \\
\hline 313 & 5.60 & -8.3 & & \\
\hline 323 & 2.94 & -11.0 & & \\
\hline
\end{tabular}

Furthermore, values of entropy, $\Delta \mathrm{S}^{\circ}$, for $\mathrm{Pb}(\mathrm{II})$ and $\mathrm{Cr}(\mathrm{VI})$ adsorption onto AAJPL were 369.3 and $274.4 \mathrm{~J} / \mathrm{mol} \mathrm{K}$, respectively. Positive values indicate increased randomness in interactions at the solid-liquid interface during the adsorption process. Results in Table 2 suggest that the biosorption is an endothermic process, i.e., increase in removal efficiency with increasing temperature.

\subsection{Biosorption Kinetics}

To investigate the kinetics of the adsorption process, two kinetic models were examined: pseudo-first order and pseudo-second order kinetics. The pseudo-first order model can be expressed as follows [29]:

$$
\ln \left(\mathrm{q}_{\mathrm{e}}-\mathrm{q}_{\mathrm{t}}\right)=\ln \mathrm{q}_{\mathrm{e}}-\mathrm{k}_{1} \mathrm{t}
$$

where $\mathrm{q}_{\mathrm{e}}$ and $\mathrm{q}_{\mathrm{t}}$ are amounts of ions $(\mathrm{mg} / \mathrm{g}$ ) adsorbed at equilibrium and time $(\mathrm{t})$, respectively, and $\mathrm{k}_{1}$ is the adsorption rate constant. Pseudo-second order kinetics model (Equation (14)) was also fitted to the experimental data. Figure 8 shows that biosorption of both $\mathrm{Pb}$ (II) and $\mathrm{Cr}(\mathrm{VI})$ obeyed Equation (13), indicating pseudo-first order kinetics. The $\mathrm{R}^{2}$ values for the pseudo-first order kinetics were 0.997 and 0.991 for $\mathrm{Pb}(\mathrm{II})$ and $\mathrm{Cr}(\mathrm{VI})$, respectively, indicating that the adsorption system was most likely best described by the pseudo-first order kinetic model. This is in good agreement with reported conclusions [29]. It is clear from the literature that the adsorption kinetics depend on the adsorbent nature.

$$
\frac{t}{q_{t}}=\frac{1}{k_{2} q_{e}^{2}}+\frac{t}{q_{e}}
$$

\subsection{Control Experiments}

The control experiments revealed that only a negligible amount $(<0.1 \%)$ of $\mathrm{Pb}(\mathrm{II})$ and $\mathrm{Cr}(\mathrm{VI})$ ions were adsorbed by walls of the glass bottles and magnetic stirrer. Results also reveal that the removal efficiency of the inactivated Juniperus procera leaves was much lower than those obtained using the AAJPL. Removal efficiencies measured for the inactivated leaves were $25 \%$ and $21 \%$ for $\mathrm{Pb}$ (II) and $\mathrm{Cr}(\mathrm{VI})$ ions and for activated leaves were $98 \%$ and $96 \%$, respectively. These results indicate that acid activation of Juniperus procera leaves was the determinant factor in removal of $\mathrm{Pb}(\mathrm{II})$ and $\mathrm{Cr}(\mathrm{VI})$ ions. 


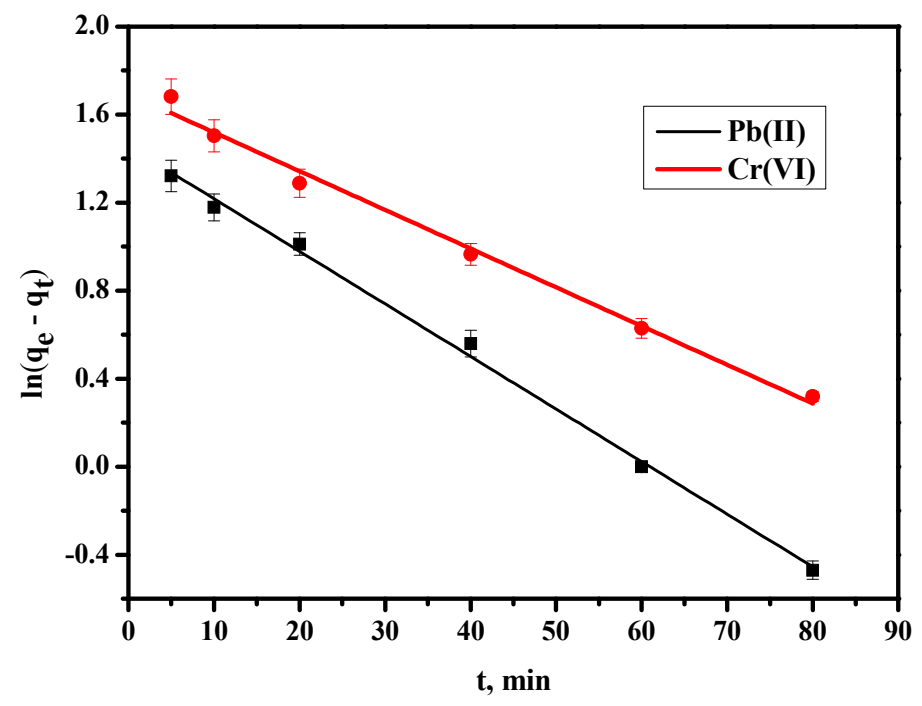

Figure 8. Linear fit of experimental data obtained using pseudo-first order kinetics model (adsorbent mass: $0.80 \mathrm{~g} / 100 \mathrm{~mL}$ for $\mathrm{Pb}(\mathrm{II})$ at $\mathrm{pH} 4.6$ and $1.00 \mathrm{~g} / 100 \mathrm{~mL}$ for $\mathrm{Cr}(\mathrm{VI})$ at $\mathrm{pH} 4.0$; metal ion concentrations: $50 \mathrm{mg} / \mathrm{L}$ for $\mathrm{Pb}(\mathrm{II})$ and $70 \mathrm{mg} / \mathrm{L}$ for $\mathrm{Cr}(\mathrm{VI})$; temperature: $25.0^{\circ} \mathrm{C}$ ).

\subsection{Reactivation and Reusability of AAJPL}

Results of reusing of AAJPL are presented in Figure 9. It clear that the efficiency of AAJPL decreased gradually with reuse. Results prove that AAJPL could be used 2-3 times efficiently to remove $\mathrm{Pb}(\mathrm{II})$ and $\mathrm{Cr}(\mathrm{VI})$ ions from aqueous solutions.

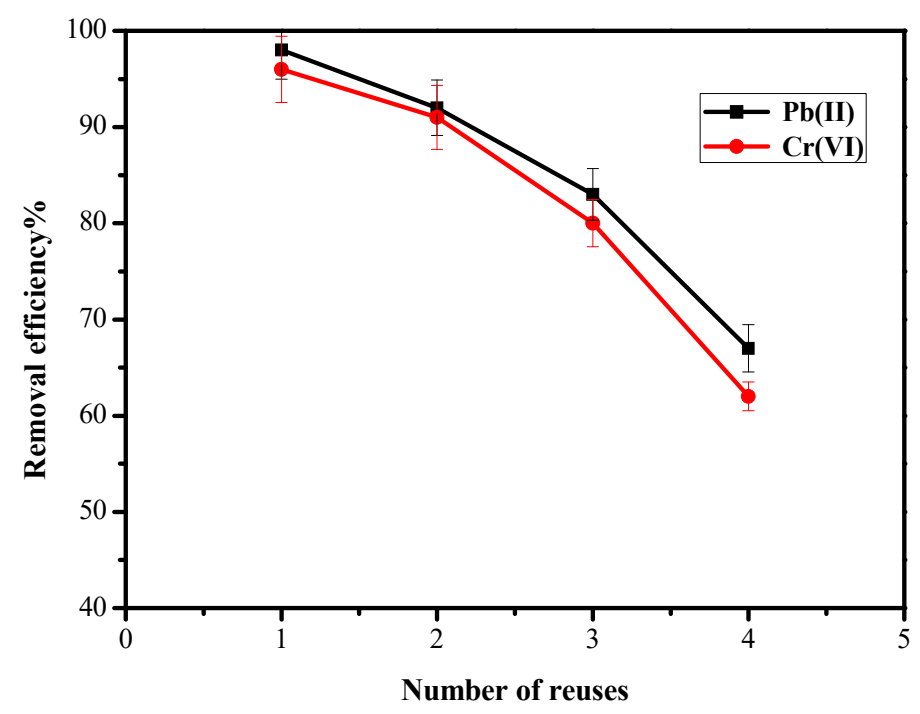

Figure 9. AAJPL reactivation and reuse.

\subsection{Comparison of AAJPL with other Sorbents}

Comparisons of maximum adsorption capacity, $\mathrm{q}_{\mathrm{m}}$, isotherm model, adsorption type and kinetics of AAJPL with those of various biosorbents reported previously are shown in Table 3 . The difference in $\mathrm{q}_{\mathrm{m}}$ values could be attributed to the properties and nature of each biosorbent. The comparison with other adsorbents proves that AAJPL can be classified an excellent biosorbent for $\mathrm{Pb}(\mathrm{II})$ and $\mathrm{Cr}(\mathrm{VI})$ ions. 
Table 3. Comparison between AAJPL and other activated carbon biosorbent.

\begin{tabular}{|c|c|c|c|c|c|}
\hline Adsorbent & $\mathrm{q}_{\mathrm{m}}$ & Kinetics & Isotherm model & Adsorption Type & References \\
\hline \multicolumn{6}{|l|}{$\mathrm{Pb}(\mathrm{II})$} \\
\hline Juniperus procera & 30.3 & 2nd order & Langmuir & physical & This study \\
\hline Tridax procumbens & 4.5 & 1st order & Langmuir & physical & [28] \\
\hline Pumpkin seed shell & 14.3 & 2nd order & Langmuir & $* *$ & [22] \\
\hline $\begin{array}{l}\text { Water Hyacinth } \\
\text { Cr(VI) }\end{array}$ & 33.4 & 2nd order & Langmuir & physical & [33] \\
\hline Juniperus procera & 23.0 & 2nd order & Langmuir & physical & This study \\
\hline Ficus nitida & 21.0 & 2nd order & Langmuir & physical & {$[34]$} \\
\hline Annona squamosal & 7.9 & 2nd order & Freundlich & chemical & {$[4]$} \\
\hline Olive stones & 25.6 & 1st order & Langmuir & $* *$ & [35] \\
\hline Rosmarinus officinalis & 1.0 & $* *$ & Langmuir & $* *$ & {$[36]$} \\
\hline Walnut hull & 98.1 & 2nd order & Langmuir & $* *$ & [31] \\
\hline
\end{tabular}

** Not Reported.

\subsection{Morphology of AAJPL Surface}

The morphology of AAJPL was investigated using scanning electron microscope (SEM). Results are displayed in Figure 10. Figure 6a clearly shows that there were many vacant pores and cavities, which facilitated the adsorption process, while Figure $6 \mathrm{~b}$ shows that these cavities were full of $\mathrm{Pb}(\mathrm{II})$ and $\mathrm{Cr}(\mathrm{VI})$ ions, indicating good adsorption efficiency of AAJPL.

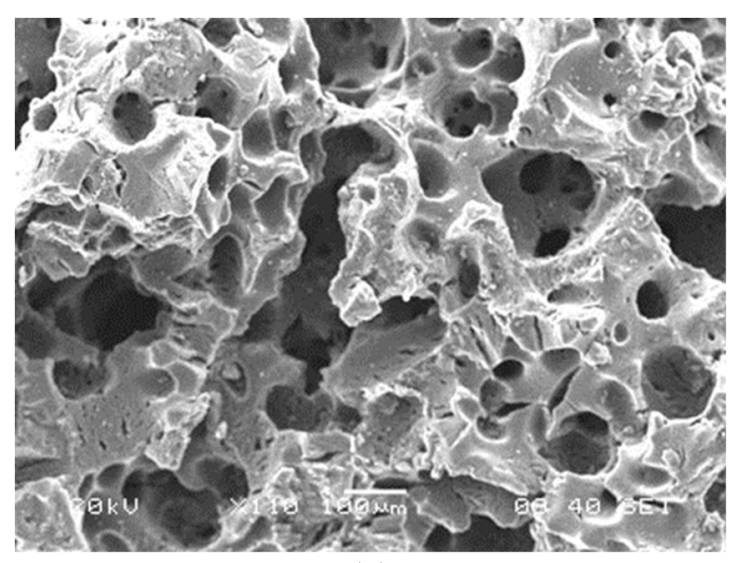

(a)

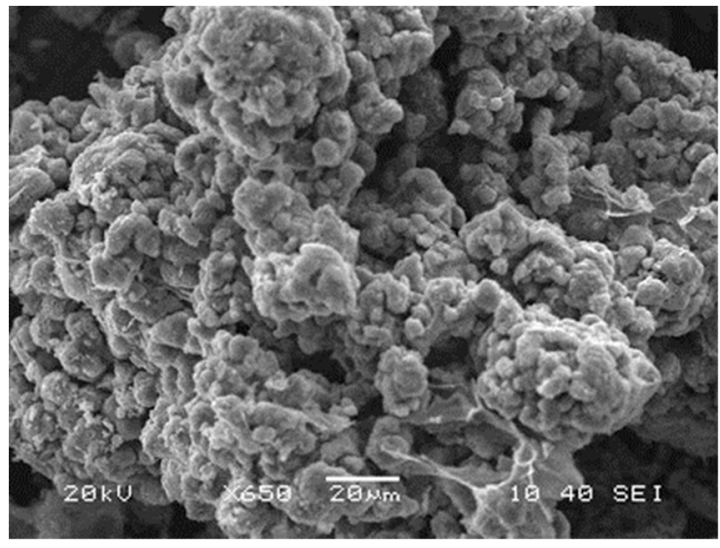

(b)

Figure 10. (a) SEM for AAJPL surface before adsorption; and (b) SEM for AAJPL surface after adsorption.

\section{Conclusions}

From the above discussion, it is concluded that AAJPL can be used as a cheap, efficient and eco-friendly biosorbent material for the removal of $\mathrm{Pb}(\mathrm{II})$ and $\mathrm{Cr}(\mathrm{VI})$ ions from aqueous solutions. The maximum removal efficiency for $\mathrm{Pb}(\mathrm{II})$ and $\mathrm{Cr}(\mathrm{VI})$ ions were $98 \%$ and $96 \%$ and obtained within 100 and $120 \mathrm{~min}$, respectively. Adsorption efficiency increased gradually when the adsorbent mass was increased up to an optimum dosage of $0.8 \mathrm{mg} / \mathrm{L}$ for $\mathrm{Pb}(\mathrm{II})$ and $1.0 \mathrm{mg} / \mathrm{L}$ for $\mathrm{Cr}(\mathrm{VI})$. The best temperature for the maximum adsorption was found to be $40.0^{\circ} \mathrm{C}$. The maximum removal of $\mathrm{Pb}$ (II) and $\mathrm{Cr}(\mathrm{VI})$ ions was achieved at $\mathrm{pH}$ of 4.6 and 4.0, respectively. Moreover, the obtained experimental data were well explained using Langmuir, Freundlich, Temkin and D-R isotherm models. In addition, for both metal ions, adsorption processes were found to be endothermic, spontaneous and following pseudo-first order kinetics. AAJPL could be reused efficiently three times.

Author Contributions: Data curation, M.D.; Formal analysis, I.H.A. and M.I.K.; Funding acquisition, M.K.A.M.; Methodology, I.H.A.; Supervision, M.K.A.M.; Validation, I.H.A.; Writing-original draft, M.I.K.; and Writing-review and editing, M.M.A. 
Funding: The authors extend their appreciation to the Deanship of Scientific Research at King Khalid University for funding this work through research groups program under grant number R.G.P.1/97/40.

Conflicts of Interest: The authors declare no conflict of interest.

\section{References}

1. Ali, I.H.; Ateeg, A. Study of SoilPollutants inOmdurman IndustrialArea, Sudan, Using X-ray Fluorescence Technique. Int. J. Environ. Res. 2015, 9, 291-294.

2. Ali, I.H.; Sulfab, A. Concurrent two one-electron transfer in the oxidation of chromium (III) complexes with trans-1,2-diaminocyclohexane- $N, N, N^{\prime}, N^{\prime}$-tetraacetate and diethylenetriaminepentaacetate ligands by periodate ion. Int. J. Chem. Kinet. 2012, 44, 729-735. [CrossRef]

3. Kumar, R.; Arya, D.K.; Singh, N.; Vats, H.K. Removal of Cr (VI) Using Low Cost Activated Carbon Developed by Agricultural Waste. J. Appl. Chem. 2017, 10, 76-79. [CrossRef]

4. Krishna, D.; Sree, R.P. Removal of chromium from aqueous solution by Custard apple (Annona squamosa) peel powder as adsorbent. Int. J. Appl. Sci. Eng. 2013, 11, 171-194.

5. Mohanty, K.; Jha, M.; Meikap, B.C.; Biswas, M.N. Removal of chromium (VI) from dilute aqueous solutions by activated carbon developed from Terminalia arjuna nuts activated with zinc chloride. Chem. Eng. Sci. 2005, 60, 3049-3059. [CrossRef]

6. Kobya, M. Removal of $\mathrm{Cr}(\mathrm{VI})$ from aqueous solutions by adsorption onto hazelnut shell activated carbon: Kinetic and equilibrium studies. Bioresour. Technol. 2004, 91, 317-321. [CrossRef]

7. Bulut, Y.; Tez, Z. Removal of heavy metals from aqueous solution by sawdust adsorption. J. Environ. Sci. 2007, 19, 160-166. [CrossRef]

8. Honnannavar, S.M.; Hampannavar, U.; Hegde, P. Removal of Hexavalent chromium from wastewater by using activated sugarcane bagasse as an adsorbent. J. Environ. Sci. Sustain. 2013, 1, 120-123.

9. Rai, M.K.; Shahi, G.; Meena, V.; Meena, R.; Chakraborty, S.; Singh, R.S.; Rai, B.N. Removal of hexavalent chromium $\mathrm{Cr}(\mathrm{VI})$ using activated carbon prepared from mango kernel activated with $\mathrm{H}_{3} \mathrm{PO}_{4}$. Resour.-Effic. Technol. 2016, 2, S63-S70. [CrossRef]

10. Elabbas, S.; Mandi, L.; Berrekhis, F.; Pons, M.N.; Leclerc, J.P.; Ouazzani, N. Removal of Cr (III) from chrome tanning wastewater by adsorption using two natural carbonaceous materials: Eggshell and powdered marble. J. Environ. Manag. 2016, 166, 589-595. [CrossRef] [PubMed]

11. Ahmed, I.; Attar, S.; Parande, M. Removal of Hexavalent Chromium (Cr (VI)) from Industrial Wastewater by Using Biomass Adsorbent (Rice Husk Carbone). Int. J. Adv. Eng. Stud. 2012, 1, 92-94.

12. Meunier, N.; Laroulandie, J.; Blais, J.F.; Tyagi, R.D. Cocoa shells for heavy metal removal from acidic solutions. Bioresour. Technol. 2003, 90, 255-263. [CrossRef]

13. Moyo, M.; Chikazaza, M.; Nyamunda, B.C.; Guyo, U. Adsorption Batch Studies on the Removal of Pb(II) Using Maize Tassel Based Activated Carbon. J. Chem. 2013, 2013, 508934. [CrossRef]

14. Bernard, E.; Jimoh, A.; Odigure, J. Heavy metals removal from industrial wastewater by activated carbon prepared from coconut shell. Res. J. Chem. Sci. 2013, 3, 3-9.

15. Badmus, M.; Audu, T.; Anyata, B. Removal of lead ion from industrial wastewaters by activated carbon prepared from periwinkle shells (Typanotonus fuscatus). Turk. J. Eng. Environ. Sci. 2007, 31, 251-263.

16. Khan, M.A.; Alemayehu, A.; Duraisamy, R.; Berekete, A.K. Removal of Lead ion from aqueous solution by Bamboo activated Carbon. Int. J. Water Res. 2015, 5, 33-46.

17. Li, M.; Zhang, Z.; Li, R.; Wang, J.J.; Ali, A. Removal of $\mathrm{Pb}(\mathrm{II})$ and $\mathrm{Cd}(\mathrm{II})$ ions from aqueous solution by thiosemicarbazide modified chitosan. Int. J. Biol. Macromol. 2016, 86, 876-884. [CrossRef] [PubMed]

18. Senthil Kumar, P. Adsorption of lead (II) ions from simulated wastewater using natural waste: A kinetic, thermodynamic and equilibrium study. Environ. Prog. Sustain. Energy 2014, 33, 55-64. [CrossRef]

19. Rahman, M.M.; Adil, M.; Yusof, M.A.; Kamaruzzaman, B.Y.; Ansary, H.R. Removal of Heavy Metal Ions with Acid Activated Carbons Derived from Oil Palm and Coconut Shells. Materials 2014, 7, 3634-3650. [CrossRef]

20. Tahiruddin, N.S.M.; Ab Rahman, S.Z. Adsorption of lead in aqueous solution by a mixture of activated charcoal and peanut shell. World J. Sci. Technol. Res. 2013, 1, 102-109.

21. Reddy, D.H.K.; Seshaiah, K.; Reddy, A.V.R.; Rao, M.M.; Wang, M.C. Biosorption of Pb21 from aqueous solutions by Moringa oleifera bark: Equilibrium and kinetic studies. J. Hazard. Mater. 2010, 174, 831-838. [CrossRef] 
22. Okoye, A.; Ejikeme, P.; Onukwuli, O. Lead removal from wastewater using fluted pumpkin seed shell activated carbon: Adsorption modeling and kinetics. Int. J. Environ. Sci. Technol. 2010, 7, 793-800. [CrossRef]

23. Yao, S.; Zhang, J.; Shen, D.; Xiao, R.; Gu, S.; Zhao, M.; Liang, J. Removal of Pb(II) from water by the activated carbon modified by nitric acid under microwave heating. J. Colloid Interface Sci. 2016, 436, 118-127. [CrossRef]

24. Taha, M.F.; Kiat, C.F.; Shaharun, M.S.; Ramli, A. Removal of Ni(II), Zn(II) and Pb(II) ions from single metal aqueous solution using activated carbon prepared from rice husk. Int. J. Environ. Ecol. Eng. 2011, 5, 855-860.

25. Azouaou, N.; Sadaoui, Z.; Mokaddem, H. Adsorption of Lead from Aqueous Solution onto Untreated Orange Barks: Equilibrium, Kinetics and Thermodynamics. In Proceedings of the E3S Web of Conferences, Guizhou, China, 22-24 September 2013.

26. Singanan, M. Removal of lead (II) and cadmium (II) ions from wastewater using activated biocarbon. Sci. Asia 2011, 37, 115-119. [CrossRef]

27. Feng, D.; Aldrich, C. Adsorption of heavy metals by biomaterials derived from the marine alga Ecklonia maxima. Hydrometallurgy 2004, 73, 1-10. [CrossRef]

28. Awual, M.R.; Hasan, M.M.; Eldesoky, E.G.; AbdulKhaleque, M.; Rahman, M.M.; Naushad, M. Facile mercury detection and removal from aqueous media involving ligand impregnated conjugate nanomaterials. Chem. Eng. J. 2016, 290, 243-251. [CrossRef]

29. Xiong, C.; Yao, C. Synthesis, characterization and application of triethylenetetraamine modified polystyrene resin in removal of mercury, cadmium and lead from aqueous solutions. Chem. Eng. J. 2009, 155, 844-850. [CrossRef]

30. Xiong, C.; Yao, C. Preparation and application of acrylic acid grafted polytetraflouroethylene fiber as a weak acid cation exchanger for adsorption of Er(III). J. Hazard. Mater. 2009, 170, 1125-1132. [CrossRef]

31. Wang, X.S.; Li, Z.Z.; Tao, S.R. Removal of chromium (VI) from aqueous solution using walnut hull. J. Environ. Manag. 2009, 90, 721-729. [CrossRef]

32. Hutson, N.D.; Yang, R.T. Theoretical basis for the Dubinin-Radushkevitch (DR) adsorption isotherm equation. Adsorption 1997, 3, 189-195. [CrossRef]

33. El-Wakil, A.M.; Abou El-Maaty, W.M.; Awad, F.S. Removal of lead from aqueous solution on activated carbon and modified activated carbon prepared from Dried Water hyacinth plant. J. Anal. Bioanal. Tech. 2014, 5, $1-14$.

34. Ali, I.H.; Alrafai, H.A. Kinetic, isotherm and thermodynamic studies on biosorption of chromium(VI) by using activated carbon from leaves of Ficus nitida. Chem. Cent. J. 2016, 10, 36-43. [CrossRef] [PubMed]

35. Attia, A.A.; Khedr, S.A.; Elkholy, S.A. Adsorption of chromium ion (VI) by acid activated carbon. Braz. J. Chem. Eng. 2010, 27, 183-193. [CrossRef]

36. Erhayem, M.; Al-Tohami, F.; Mohamed, R.; Ahmida, K. Isotherm, kinetic and thermodynamic studies for the sorption of mercury (II) onto activated carbon from Rosmarinus officinalis leaves. Am. J. Anal. Chem. 2015, 6, 1-10. [CrossRef]

(C) 2019 by the authors. Licensee MDPI, Basel, Switzerland. This article is an open access article distributed under the terms and conditions of the Creative Commons Attribution (CC BY) license (http://creativecommons.org/licenses/by/4.0/). 